\title{
The Principal Transformational Leadership Strategy in Developing National Policies for Strengthening Character Education in Eastern Indonesia
}

Yulius Rustan Effendi ${ }^{*}$ Ibrahim Bafadal ${ }^{* *}$, I Nyoman Degeng Sudana ** and Imron Arifin ***

\author{
Author information \\ * Educational Management Department, Malang State University, Indonesia. Email: fenalm.21@ \\ gmail.com \\ ** Educational Management Department, Malang State University, Indonesia. Email: ibrahim.bafadal. \\ fip@um.ac.id \\ ***_Educational Management Department, Malang State University, Indonesia. Email: sudana_daniel@ \\ yahoo.com \\ **** Educational Management Department, Malang State University, Indonesia. Email: imron.arifin.fip@
um.ac.id
}

Article first published online

June 2020

\section{HOW TO CITE}

Effendi, Y.R., Bafadal, I., Sudana, I. N. D., Arifin, I. (2020). The Principal Transformational Leadership Strategy in Developing National Policies for Strengthening Character Education in Eastern Indonesia, 12(2), 51-78.

DOI: $10.14658 /$ pupj-ijse-2020-2-3

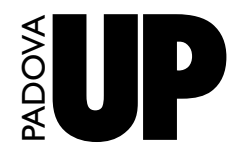




\title{
The Principal Transformational Leadership Strategy in Developing National Policies for Strengthening Character Education in Eastern Indonesia
}

Yulius Rustan Effendi, Ibrahim Bafadal, I Nyoman Degeng Sudana, Imron Arifin

\begin{abstract}
This study aims to describe the development of national education policies by uniting the main character values set by the Indonesian Ministry of Education with the moral values of the Lonto leok culture of the Manggarai community. Also, to find out and explain the role of the principal's leadership based on the Lonto Leok culture teaching approach. This research used a qualitative approach, case study design. To achieve research objectives, data collection through in-depth interviews, observation of participants, and study documentation. Data analysis used a modified analytic analysis method. Data validity is assessed based on the level of credibility, transferability, dependability, and confirmability. The results of the study explained that the school's character values derived from the unification of national character values and the cultural values of Lonto Leok culture had an effective impact on shaping the character of students at school. Besides, explaining that the application of the principal's transformational leadership role model based on the approach of Lonto Leok's cultural teaching dimensions encourages all components of the school, parents, and community to actively participate in supporting the implementation of character education strengthening programs in schools. The contribution of this research is to position the moral values of the "Lonto Leok" culture of the Manggarai community as local cultural assets that support the formation of student character. Also, the dimensions of teaching lonto leok culture affect effectively supporting the principal's transformational leadership behavior, so that the program to strengthen character education is optimally implemented.
\end{abstract}

Keywords: transformational leadership, principal, character education strengthening, character value, and lonto leok culture teaching dimension 


\section{Introduction}

Progress in the global era has unified human potential without limits, in the concept of thinking, communicating, and acting, thus presenting changes in various fields including education (Li, 2013; Cook et al., 2016). The changes that occur cause the strengthening of personal autonomy in building identity and morality (Veugelers, 2008), but on the other hand, positions humans in a dilemmatic situation, because they compete with each other, thus impacting on losing critical awareness of humanity (Giddens, 2003; Lovvorn \& Chen, 2011). The loss of a critical consciousness of man, caused by the inequality between progress and the human condition that does not have the competence and moral autonomy. The lack of competence and moral appreciation is caused by policies and the flawed pedagogical approach (Kasali, 2017). All these weaknesses plunged humans into dehumanization actions, and have an impact on moral conflict (Giddens, 2003). Moral conflict results in immoral acts and is currently experienced by students at the junior high school level in Indonesia. Actions of moral perversion are shown in forms, such as; intolerant attitudes that give birth to radical groups, fights between students, drug use, promiscuity, cheating, stealing, unethical dress, undisciplined, impolite, unethical in speaking, losing the meaning of the values of local cultural wisdom (Koesoema, 2010; Endah, 2012; Ministry of Education, 2016).

Responding appropriately to moral deviations, the Indonesian Ministry of Education has formulated a policy that requires all schools in Indonesia to promptly execute a sustainable program to strengthen character education, follow up on the implementation of character education that has been running since 2010. The Government of Indonesia has revitalized education policy contained in Government Regulation Number 87 of 2017, Chapter I, Article 1, which emphasizes that character education strengthening is an education activity to energize the moral strength of the heart, sense, mind, and body. Education activities are carried out through effective cooperation between school, parents, and community. Without reducing the present role of schools, the character education strengthening program has been optimally unimplemented at the school level. Based on the explained findings of Yaumi (2014); Wibowo (2015); Koesoema (2015), the primary cause of failure lies in the local principal's applicable policy and approach. The principal's policy of using national character values as the main character values at school confuses all school components in placing the intended values. Asserted so, because the standards of the main character values set by the Ministry of Education of Indonesia are still conceptual and contain political content rather than operational. Also, student characters have been molded by moral values and norms in a culture that shapes the patterns of behavior. 
As a result, schools have been unable to apply practical guidelines on the program implementation and assessment. Based on the arguments, it can be ascertained that the Indonesian Ministry of Education's policy of setting national main character values, without considering the uniqueness of schools based on the richness of local cultural values, is a urgent problem causing the character education strengthening program to not possess a beneficial influence. Besides, the principal's policy of using national character values standards, as a standard of character values in schools, and ignoring local cultural moral values as a standard of character values in schools, causes students to be alienated from their environment and have an impact to the confusion of finding one's identity and self-actualization. If this policy is immediately uncorrected, Indonesia's young generation in the future will lose its identity because it will no longer grow and develop based on its moral values and cultural norms.

Besides that, principals do not have an approach pattern that is appropriate to the conditions of the school environment, particularly in Manggarai, West Flores, Eastern Indonesia, which is strongly influenced by local culture. As a result, there is a separation in principle and communication between the principal and the followers. In general, school principals in Indonesia are stuck with the general concept of implementing national education strengthening, without being given the freedom to consider approaches that are appropriate to different cultural environmental conditions. Principals are not given clear instructions, they are not given a compass as a guide in using a definitive approach (Koesoema, 2010). As a result, the principal's approach pattern ignores the sense of identity and "ownership" of a particular environment, which has been formed by the same norms, rituals, values, beliefs, and language to do something (Ferraro, 1998). If this problem is not resolved immediately, the miscommunication and misorientation problems that occur between the principal, teachers, staff, parents, and the community will continue and have an impact on the uncertainty of achieving the character education strengthening program (Musana, 2011).

Responding to the weaknesses of the principal's policy and approach, in the latest findings of our study, principal at state junior high schools, in Manggarai, West Flores, Eastern Indonesia have effectively and optimally implemented programs to strengthen the character of education in school. This success is based on the principal's policy of integration of national character values with moral values of the "lonto leok" culture of the Manggarai community. Besides, the principal has an understanding of lonto leok culture, so that the principal is motivated to exert "lonto leok" culture teaching dimension as an alternative approach to supporting the principal's transformational leadership role (Sutam, 2014; Tapung et al., 2018). Transformational leadership behavior implemented by the principal as conceived 
by Leithwood \& Jantzi (1999), appears in several role models; articulate a vision, provide intellectual stimulation, offer individual support; describe competent practices and values, show expectations of high-performance, and develop structures to encourage participation in school decisions. This leadership model is integrated with lonto leok culture teaching dimension approach, following the concept of cultural leadership developed by Hofstede (2001), which explains the distance of power, uncertainty, individuality, and traditional collectivity. The integration of transformational leadership model with a cultural approach, reaffirming the thought of Hofstede (1984); Gerstner \& Day (1994); Bass (1997); House et al. (2004) that culture can influence the concepts, styles, and practices of transformational leadership to become more effective. This integration model is a culture-specific approach because leaders in the main activities need to adapt to the local cultural environment. In this context, it can be called a cross-cultural leadership model (Den Hartog et al., 1999).

Therefore, it is necessary to formulate the main character value standards in schools by integrating the value of the national character and moral values of the local culture. In addition, transformational leadership behavior is based on a cultural approach so that the implementation of education strengthening programs takes place effectively. Based on the existing thinking, this research principally describes the integration of local cultural moral values and national character values as a standard of character values in schools. This is in accordance with the conditions of Indonesia which consists of various tribes, possesses its own culture and contains local wisdom (Kleden, 1987). In addition to positioning leadership behaviors that count towards relationships with culture (Cameron \& Quinn, 1999). Integration of transformational leadership behavior with a cultural approach, affirming the thoughts of Bass (1997); Hofstede (1984); Gerstner \& Day (1994), which explains that culture can influence the concepts, styles, and practices of transformational leadership more effectively. Thus, it is important and urgent to think and formulate a model policy strengthening character education based on the result of the union between the values of the national character and moral values of the local culture as the standard of character values in schools, and the pattern of leadership approach that is based on an insight into the cultural wisdom (Musana, 2011).

Based on the description of the problem, it clearly seems the challenges in the professionalism of the leadership role of the principal in developing national education policy, especially the character education strengthening program. To explore this challenge, it is necessary to formulate research objectives, namely to describe the development of national education policies that unite the primary values of a nationally determined character (national character values) and the cultural moral values of Lonto Leok. Besides, to de- 
scribe the role model of transformational leadership of the principal through approaches that use the dimensions of teaching lonto leok culture.

\section{Education, culture and character education strengthening}

Education is a conscious effort to build the science of knowledge and the consolidation of values in students (Freire, 1978). Culture is a thinking system, motive, value, moral norm, social relation, identity, interpretation, and human belief at one point of change through human interaction with others and the natural environment (House et al., 2004; Nieto, 2008; Mason, 2013). Character is the basic existence of one's personality that is formed as the results of internalization of various virtues, as a basis for thinking, behaving, and acting (CEP, 2002). Ryan \& Bohlin (1999) clearly states that moral virtue is directly related to moral character, because the moral character is usually based on values both derived from culture and religion. An effective moral life always requires the practice of human virtue based on the values of true faith. The internalization of virtue forms good character. Good character means knowing about good, wanting good, and doing good. Virtue is not only related to the values or qualities that are useful, but a fundamental force to obtain something valuable. Therefore, religious ethics is a character of faith or virtue of faith expressed in the form of commands, norms, and virtues. The basic motivation for ethical action aims to glorify God and be useful for oneself and others (Groome, 1991). Therefore, characters are special good values (know about goodness, want to do good, obtain a noble life, and benefit the environment. All forms of good values are manifested in good behavior (Lickona, 2004).

In the era of the Industrial Revolution 4.0, it is not just needed students who are strong in character, but also true, positive, and constructive. Therefore developing these characters requires pedagogic strategies such as; a) condition a school environment that is orderly, disciplined, respectful, friendly, polite in speaking, polite in dress, and tolerant in responding to differences. This condition is applied through habituation and imitation of the teacher's behavior so that it is imitated by students. b) condition the classroom environment through strategy development learning that can foster student character such as; child-friendly, fun, appreciate honesty, fair treatment, free to convey thoughts, respect the opinions of others, guide students with love, solve students' problems with empathy, understanding, and tenderness, free of bullying; c) condition the family and community environment by giving an exemplary behavior by local values and cultural norms.

For the school environment, classrooms, and society to be optimally conditioned, it is necessary to develop a culture of inclusion and evolution (Ladson-Billings, 1992c; Nieto, 2008). The development of an inclusive culture is 
an effort to habituate life in the school environment in ways that are open, friendly, democratic, feel safe and comfortable, fair treatment, including all people with different backgrounds, characteristics, abilities, status, conditions, ethnicity, culture (Koesoema, 2015; Ministry of Education, 2017). While evolutionary culture shows that culture is dynamic, active, changing, always moving Culture is always changing, because it is influenced by the political, social, and economic conditions in which it is found (Erickson, 1997; Nieto, 2008). Associated with several conditions that affect cultural change, the school as a social organization needs to anticipate negative changes that are influenced by conditions that occur (Koentjaraningrat, 1998). The school's efforts are to prepare a curriculum that is morally charged, instill moral values through learning activities, familiarize students with practicing values of honesty, fairness, tolerance, kinship, mutual respect, mutual care. Besides, teachers need to introduce and practice living behaviors that are by cultural and religious moral values and norms, as a shield to strengthen students' moral security (Nieto, 2008; Ministry of Education, 2017).

Character education strengthening is a pedagogical activity that unites hearts, feelings, minds, and intentions, which is carried out through cooperation between schools, parents, and the community to form the student's character (Ministry of Education, 2017). Thus, Education-based on character strengthening is a planned effort to develop the potential of thinking, values, morals, social relations and beliefs of students, which are inherited and used for survival in the present and future (Lickona, 1996; UNESCO, 2012). Education that strengthens character supports the universalism approach of human development. The universalism approach is the core of the human development approach. The purpose of this approach is to give freedom to all human beings to develop their full potential now and in the future (United Nations, 2016). The same spirit is formulated in the 2030 agenda and the goal of sustainable development - without leaving anyone behind. So human development must be ensured for everyone, given the uneven human development in the global era. These barriers appear in a crisis of moral values and social and humanitarian (violence, discriminatory laws, social norms exclusive, imbalance in political participation, the uneven distribution opportunities, intolerance). Responding to these obstacles, it is necessary to refocus the educational approach that has the character formation content. A person with character has a heart, mind, and actions to strive to create mutual peace and social prosperity, partner with one another and seek a balance between humans and the planet (United Nations, 2016).

Therefore, character strengthening can only be processed in certain social and cultural environments (Nieto, 2008). In addition to conditioning the school's internal environment, the application of strengthening character education must be by local socio-cultural values. The reason is that every 
region in Indonesia already has values, norms that have shaped the lives of local people. Therefore, the school environment needs to be integrated with local socio-cultural values and norms, so students are not isolated from the social environment of their lives. Schools as social institutions are responsible for processing cultural values. That is, teachers, parents, and the community are responsible to introduce, accustom students to behave by the values, norms, and ethics that apply in the local cultural environment (Kleden, 1987; Hintze et al., 2015). Helping students to take social roles and teaching them to perform their roles. That is, in social life students should behave by the demands of values, norms, and ethics that apply. Therefore, the responsibilities of teachers, parents and the community should set an example of behavior so that students can model the behavior (Dister, 1998). Incorporating student identity into a broader scope of culture. That is, in addition to living in a school environment, students also need to unite and adapt to life in the wider community with all its demands (Todd, 2001). Developing and maintaining the noble values of the culture. That is, by behaving by the values, norms, and ethics that apply in society, students in this context have grown and developed as individuals who know to respect prevailing habits, so as not to harm themselves and society as a whole (Dister, 1998). Developing critical awareness to oppose the status quo of social order and becoming the agent of change in the development of social innovation (Ladson-Billings, 1992c; Tilaar, 2005). That is, forming critical awareness in students so that they behave well based on goodwill, even though dealing with habits in the wrong society (promiscuity, smoking, drinking liquor, brawls between students, rape, injustice, corruption). Besides behaving well based on goodwill so that it becomes a role model in association in the community (Colin, 1996).

\section{Transformational leadership of principal in character education strengthening}

The presence of a leader within the organization is very important to deal with the changes. The changes do not occur because of the leader's actions toward others, but the leader's actions along with others (Colbert, Nicholson, \& Kurucz, 2018). The presence of such leaders is in line with the thoughts of Podsakoff et al. (1990); Bass (1997); Leithwood \& Jantzi (1999); Hofstede (2001); Spreitzer, Perttula \& Xin (2005), who explain that the effectiveness of leaders in leading is influenced by local cultural conditions. Different cultural characteristics in society require adaptive leadership behavior. This dimension rejects traditional authoritarian leader behavior and keeps a distance between leaders and subordinates (Hofstede, 1993; Leithwood \& Jantzi, 1999; Spreitzer, Perttula \& Xin, 2005; Sutam, 2014). Besides, the presence of leaders supports the moral imagination of followers, 
thereby strengthening positive emotions, rationality, spirituality, and caring, and relationships with others (Leithwood, 1992; Lickona, 1992; Leithwood \& Jantzi, 2006; Koesoema, 2016; Waddock, 2016). Building trust, integrity, harmony, and morality in followers (Leithwood \& Jantzi, 2006; Veugelers, 2008; Werhane, 2008). Furthermore, in the context of national and state life, the presence of leaders becomes a person who is "Pancasilais" to encourage followers to respect diversity through tolerance and respect for national culture (Leithwood \& Jantzi, 2006; Mutrofin, 2007; Koesoema, 2010; Ministry of Education, 2016). Able to anticipate and overcome the condition of the loss of awareness of loving the nation, caused by separatist movements in the name of religion, as well as the threat of radical Islamic groups to overthrow the legitimate government (Leithwood \& Jantzi, 2006; Ministry of Education, 2017; Kasali, 2017). Prioritizing attitudes respecting individual differences, honesty, love, acting rightly, faithfully, moral consistency, not corruption, fair, respecting human dignity, and good personality (DeCavalho, 1991; Lickona, 1992; Leithwood \& Jantzi, 2006; Ministry of Education, 2017).

The presence of a leader supports the relationship and dialogue between leaders and their followers in several aspects such as; followers find meaning and vision in the workplace, persuasive communication, participation and autonomy, fair treatment, constructive feedback, development of personal and organizational goals, and role model (Leithwood \& Jantzi, 2006). In the context of social roles, transformational leadership openly positions the role of feminists (Antrobus, 2002). Feminist transformational leadership promotes gender equality from the dominance of masculinity; fighting for radical social change; prioritizing collective interests, especially marginal groups; implement governance in a transparent, accountable, relational, horizontal and dialogical manner; run a system of power and joint decisions, not "over" the decisions of others; inspire excellence, productivity that exceeds expectations and creates opportunities for self-actualization by personal and organizational goals; modeling the behavior of others, offering opportunities for professional work development (Vassell, 2001; Antrobus, 2002; Batliwala, 2011). In the context of educational organizations, Leithwood \& Jantzi (1999) explain that the application of transformational leadership models has a positive effect in the field of education, especially in achieving cooperation that supports the learning and mentoring character of teachers and students. Is required because there are professional values and standards and how an individual develops their character through mentoring is a personal journey with clear ethical frameworks open to the moral inquiry that are explicitly understood by all in terms of rights and duties that are revealed through acts that do not harm the self and the other are all have access to mitigation without duress. 
In the context of character education strengthening, according to Podsakoff et al. (1990); Koesoema (2015), the transformational leadership role of principal at school aims at; 1) Give an ideal influence to followers through openness, selflessness, respect for individual dignity in running the organization, so that it is in line with the interests of followers and the overall progress of the organization. 2) Motivating and inspiring followers by showing empathy and optimism, involving followers to think about prospects by designing programs to strengthen the character education which include; (a) personal development activities through routine activities such as; flag ceremony, cleaning class, praying before and after learning. Programmed activities through personal guidance and counseling; (b) class activities by creating pleasant learning conditions, respecting students' minds, listening to each other in discussions, being open to receiving input and criticism, and being free to argue; (c) activities in the school environment, through extracurricular activities, and habituation and exemplary good behavior; and (d) activities in the community through social service activities, giving donations to orphanages and nursing homes, donating to the families of deceased students or teachers, friendship visits to other schools. 3) Provide intellectual stimulation openly, humbly acknowledge followers' ideas, appreciate and appreciate the competence of followers in exploring new ways that are more effective in solving learning problems. 4) Respect for individual differences, not authoritarian, but delegate duties and responsibilities, create dignified and familial communication, respect for followers' needs. 5) Building a working partnership that respects each other, avoids stressful working conditions, accepts the strengths and weaknesses of followers, and gives examples of life behaviors that know to respect others. 6) Avoiding selfish roles, using power arbitrarily, and acting without regard for followers' human rights. 7) Avoid the habit of blaming the teacher in supervision activities, but correcting the teacher's mistakes politely without ignoring the teacher's self-esteem and authority. 8) Creating a teacher's working environment that is harmonious, safe, and fun. 9) Building partnerships between schools, parents, government, and communities that are more valuable to families, cooperation, openness, participation, and willingness to support better education progress.

\section{Moral values of lonto leok culture, manggarai community, West Flores - East Indonesia}

Lonto leok is one of the cultural heritages in Manggarai. The word "lonto leok" consists of two words, which are "lonto" means to sit, and "leok" means circle. Therefore, lonto leok means sitting in a circle during a meeting and traditional ceremony (Verheijen, 1967). Lonto leok culture takes the 
symbol of Manggarai traditional house (Mbaru Gendang) in the form of a circle, and the model of agricultural land division (Manggarai: lodok) that forms a cobweb (Dagur, 1997; Sutam, 2014). The cultural symbol of lonto leok is described as follows.

Figure 1 - Cultural symbol of "Lonto Leok" (Mbaru Gendang and Lingko/Lodok)

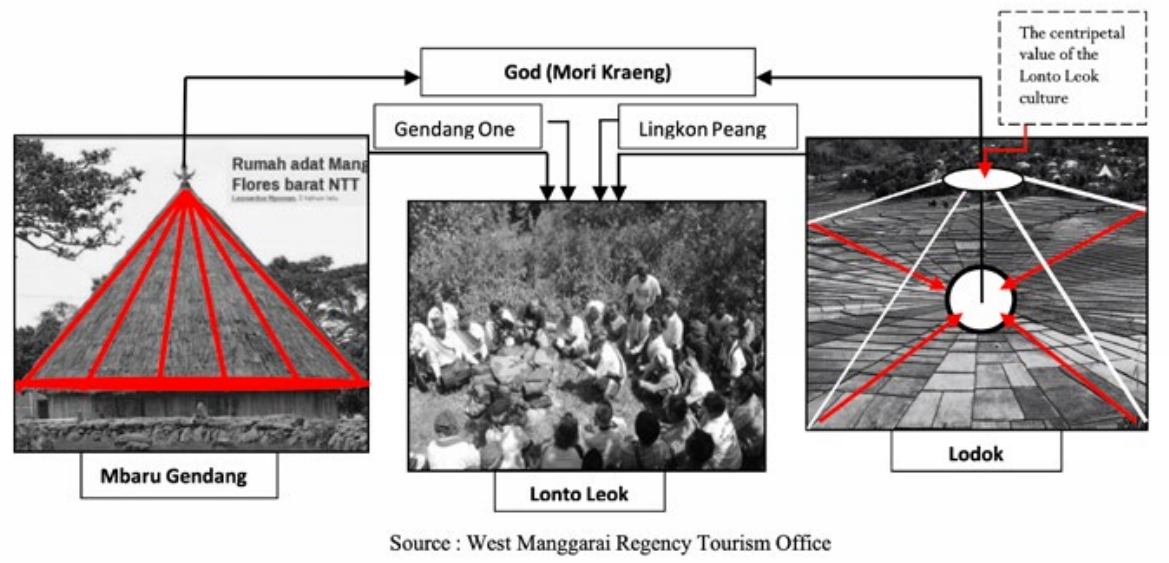

Figure 1, emphasizes on two philosophical meanings of the Manggarai people's life, that are: (1) traditional house (Manggarai: mbaru = house; gendang $=$ together), which is circular in shape and leads to the top forming a cone. This symbol means that all human activities on earth are focused on "Mori Kraeng" (Manggarai: Mori Kraeng, English: God); (2) agricultural land (lodok) in the form of cobwebs. This symbol means that human life on earth always moves towards the center of life (centripetal), which is "Mori Kraeng" = God (Sutam, 2014).

The cultural symbol of Lonto Leok inspires Manggarai people to idealize a harmonious life and a spiritual life. The form of harmony in life is formed through the appreciation of moral values, such as; (1) democracy, which prioritizes openness, respect, and humility in accepting the opinions of others, discussions that give priority to the ethics of speaking, and every decision making takes into account the interests of many people; ( 2 unity, which emphasizes a harmonious life, harmony, respect for differences, avoid conflict, establish open communication without discrimination; (3) peace, which demands a peaceful, calm life, avoids hostility, does not demean others, does not seek fault with others, and does not speak of the ugliness of others; (4) love, which is shown in the attitude of accepting others with all its limitations, caring for the poor, giving assistance to people who experience 
shortages, willing to sacrifice for the happiness of others, doing something that does not harm others; (5) justice, which is shown through selflessness, respecting the rights of others, treating others equally before the rules and laws, not taking the rights of others; (6) honesty, applied through an open attitude, speaking according to facts, not manipulative, admit mistakes, admit the strengths of others, do not transfer the blame on others; (7) hard work, as evidenced by enthusiasm at work, not giving up, being responsible for work, and valuing work; (8) hospitality, which is shown through the attitude of accepting others, open in communication, keep the attitude of revenge and hatred toward others, speak polite and ethical, and not quickly judge the mistakes of others (Sutam, 2014; Tapung et al., 2018). Transformational Leadership of Principal based on Lonto Leok Culture Teaching Dimension in Character Education Strengthening

About the concept of culture, the transformational leadership model developed by Leithwood \& Jantzi (1999); Hofstede (1984), explains that the effectiveness of transformational leaders can be influenced by the cultural environment. The culture emphasizes the sense of identity and "ownership" of certain groups through norms, rituals, values, beliefs, and languages to do something (Ferraro, 1998). Therefore, different cultural characteristics in society demand adaptive transformational leadership behaviors. That is, cultural characteristics are the result of mutual agreement, are adaptive (change and develop dynamically), can be learned, so that all patterns of thinking, feelings, and actions of a leader must be by the principles of values and beliefs that apply (Triandis, 1993). Thus, the existence of culture can influence the concepts, styles, and practices of transformational leadership. This concept supports the history of Manggarai people, where long ago, both the village elder "tua golo" (tua: elders; golo: region), and Raja (Manggarai: Dalu) as the community leaders, had placed the relationship of "lonto leok" culture dimension with transformational leadership practices. The fusion of this transformational leadership model and cultural dimension is typical of the Manggarai leadership model (Dagur, 1997; Sutam, 2014; Tapung et al., 2018).

Transformational leadership practices, supported by the lonto leok culture teaching dimension, have philosophical content that is valuable in the moral teachings of life. Moral culture teaching of Lonto Leok that supports the role of transformational leadership consists of, a) "tatong" (encouraging development and change). Its philosophical meaning is that "everything in the world is constantly changing and that nothing remains in its initial state." The transformative value of teaching this culture supports the behavior of leaders who work professionally for the betterment and change of education by the shared vision and mission. b) "toing" (life lesson). Its philosophical meaning is that "day by day human life increases and ends in death" because it is necessary to fill life with activities that benefit themselves and others." 
This transformative value of cultural teaching supports the behavior of leaders who provide stimulation of knowledge to followers, through guidance, training, and further study, so that followers can be creative and innovative in teaching activities. c) "titong" (giving guidance in life). Its philosophical meaning is that "everyone must have responsibilities in life." The transformative value of this cultural teaching supports the behavior of leaders who work openly, transparently, accountably, and participative so that educators are motivated to be involved in supporting the work of leaders. d) "tatang or titing" (empowering the potential of others). Its philosophical meaning is that "every person needs to help and support the other person." The transformative value of this cultural teaching supports the behavior of leaders who provide inspirational motivation, through behavior that trusts the teacher, appreciates the work of the teacher, allows the teacher to take part in training, thereby encouraging the professionalism of the teacher's work. e) "toto nai bakok" (caring). Its philosophical meaning is that "every person must be sincere to support and love another person". This transformative value of cultural teaching supports the behavior of leaders who recognize and value contributions, empathy, and respect for the needs of teachers and students. f) "bantang cama reje leleng "(cooperation). Its philosophical meaning is that "all humans need the presence of other humans in life". This transformative value of cultural teaching supports the behavior of leaders who involve parents and the community in supporting school programs (Sutam, 2014).

Through this integration, and referring to the thought of Hofstede (1984); Podsakoff et al. (1990); Leithwood \& Jantzi (1999); Sutam (2014); Tapung et al. (2018), several practical steps in educational leadership are developed in optimizing the character education strengthening at schools. First, to encourage school development based on a shared vision, the principal applies the teaching dimension of "Lonto Leok" in the form of "tatong" (encouraging development and change). Through this dimension, the principal motivates the followers to work according to the demands of change. Explicitly, this dimension opposes the behavior of traditional leaders who tend to maintain the status quo. Second, intellectual stimulation, applied in the form of "tatang or titing" (empowering) and "toing", (life lesson), which aims to empower followers to create and innovate to develop new ideas in work and problem-solving. Third, caring for individuals, in line with lonto leok teaching dimension in the form of "toto nai bakok" (caring). This dimension shows the sincerity to respect, care for the needs and self-esteem of followers. Fourth, practice and professional value. The dimension of lonto leok teaching is applied in the form of "titong" (giving guidance in life). That is, the leader becomes a guide, and a role model for subordinates at work. This dimension rejects traditional authoritarian leader behavior that keeps a distance between leaders and subordinates. Fifth, high-performance 
expectations. The lonto leok teaching dimension is practiced in the form of "tatang or titing" (strengthening and empowering). Here, the leaders give motivation that encourages subordinates to do more than they should be targeted. This dimension opposes the culture of individualistic conformity and applies the culture of collectivistic conformity in a framework for achieving harmony through adherence to shared norms to achieve collective goals (Bond, 2004; Schultz \& Estrada-Hollenbeck, 2008; Riggio, 2009; Baumeister \& Finkel, 2010). Besides opposing nepotism, related to the appointment, placement, appointment, and promotion system based on blood ties, family, and close friends not based on competency skills and professional work quality (Rahardjo, 1998). Furthermore, opposing "pseudo" loyalty, with a mode of work so that the leader likes. Sixth, the development of structures for participation. The lonto leok teaching dimension is applied in the form of "bantang cama reje leleng" (cooperation), which is the presence of leaders to create a harmony to achieve common goals. It emphasizes gender equality and opposes the individual role of leaders in exercising power and dominance of masculinity in traditional culture.

\section{Methodology}

\section{Research design}

This study used a descriptive qualitative analytic research design, which aims to collect data in written or oral form, arranged in sentences based on interviews with informants (Denzin \& Lincoln, 2000; Miles, Huberman \& Saldaña, 2014). This study refers to in-depth interviews with one principal, eight senior teachers, three senior employees, three students representing grades VII, VIII, and IX, two school committee staff, three parents representing the parent group, one representing the alumni, one supervisor who representing the local Education Agency, and two cultural figures. This research develops a case study on the role of the principal's leadership based on the dimensions of the lonto leok cultural teaching approach to the Manggarai community in implementing a program to strengthen character education. Concerning research ethics, using pseudonyms to protect the identities of schools and informants. To answer the research objectives, this case study used the following three questions:

1. What does the principal do in developing national policies related to the implementation of character education strengthening programs?

2. How is the process of uniting national policies, especially national character values with the context of local cultural wealth?

3. What are the steps were taken by the school principal and using what approach in implementing the character education strengthening program? 
Determination of informants through techniques; first, purposive sampling, selecting informants who know deeply the role of the principal in carrying out activities to strengthen character education. Second, snowball sampling through information gathering activities from one informant to other informants continuously so that a lot of data is collected in detail, and ends when the data collected has been saturated.

The interview begins with the school principal to determine the general role of the principal to optimize the implementation of the program of strengthening character education. Next, the researcher requested information from the principal regarding the names of teachers, staff, school committees, school supervisors who provided further information regarding the role of the school principal. While interviews with students were carried out randomly, after asking for approval from the student affairs teacher. Interviews with parents were random, depending on their opportunities and interests in visiting the school. Whereas interviews with school committee staff were conducted in a private home-based on names and addresses provided by the school principal. Besides, making direct observations to record various curricular and extracurricular events or activities that support the strengthening of student character in school (Altheide \& Johnson, 2000; Miles, Huberman \& Saldaña, 2014).

\section{Data-analysis techniques}

Data analysis was carried out through the process of systematically searching and organizing interview transcripts and field notes, then sorting and grouping data to compile research focus and generate theories (Cresswell, 2009; Miles, Huberman \& Saldaña, 2014). What we do in the process of data analysis is to describe in detail about the situation or event that gives the message the value of character formation. Statement from everyone about the experience of their involvement in character-building activities, their attitude in supporting the character formation program, their belief in all the activities that have been carried out, their thoughts that describe the overall character-building activities in school. Besides observing interactions and behaviors that give researchers an idea that good character has formed at school (Miles, Huberman \& Saldaña, 2014; Yin, 2017).

\section{Checking data validity}

The data validity in this research used several measures as follows; First, credibility measure. The purpose of data credibility was to prove the data suitability with the facts in the research. To establish the data validity, the researchers used the following inspection techniques: 1) extending involvement, thus allowing the credibility level to be increased in the data collected. By extending the involvement, the accuracy of information was obtained, and subject trust was formed. Therefore, the researchers extended the par- 
ticipation that occurred in the research background. 2) The persistence of observation meaning that the researchers looked for and found in detail the characteristics and elements in situations that were relevant to the problem being studied. 3) Triangulation helped the data checking by comparing it to other data. This was carried out in several phases; (a) source triangulation by; (1) comparing observation data with interview data; (2) comparing what was said in public with what was said privately; (3) comparing what people said about the research situation with what they said all the time; (4) comparing one's circumstances and perspectives with other's views; (5) comparing the results of interviews with the contents of related documents. (b) The triangulation method was carried out by checking the credibility level in the research findings based on several data sources with the same method. (c) Theory triangulation compared facts with one or more theories as a comparative explanation. 4) Peer examination was performed through discussion with a peer. 5) Negative case analysis, by collecting examples of cases that were not based on patterns and trends of information that had been collected and used as a comparison. 6) examining members, to check whether the data recorded and interpreted by the researchers was appropriate and the truth was recognized by key informants. Second, transferability was done through careful research reports that referred to the research focus. Third, dependability was carried out to check or evaluate the accuracy of researchers in conceptualizing the data constantly. Fourth, confirmability was carried out through testing to assess the results of research, mainly related to the description of research findings and discussion of research results (Creswell, 2009; Miles, Huberman \& Saldaña, 2014; Yin, 2017).

\section{Findings}

\section{National education policy development}

The school has set standards for school character values. The determination of school character values is the development of national policy, which unites national character values and Lonto Leok's moral values. In connection with the process of determining the value of school characters, explained by the principal:

Some of the things I do: first, involve teachers, parents, school committees, school foundations, traditional leaders and cultural activists. Second, it provides an opportunity for two cultural experts to present Lonto Leok cultural material. Third, give the task to the discussion participants to determine the school's character values based on the results of the unification of national character values and lonto leok cultural values. Fourth, form a special team to formulate the vision, mission, and goals of character education. Fifth, assign a work team 
to design a Lonto Leok-based character strengthening program which includes; personal development activities, class activities, activities in the school environment; and the community environment.

The school's character values are school branding, as a mobilizer to unite the mind, heart, and actions through learning, role-modeling, and habituation. The following is a standard picture of the school's character values as a result of the union of national character values and the moral values of the lonto leok culture of the Manggarai community.

Figure 2 - National Policy Development: School Character Values as a Result of the Integration of National Character Values and Lonto Leok Cultural Moral Values

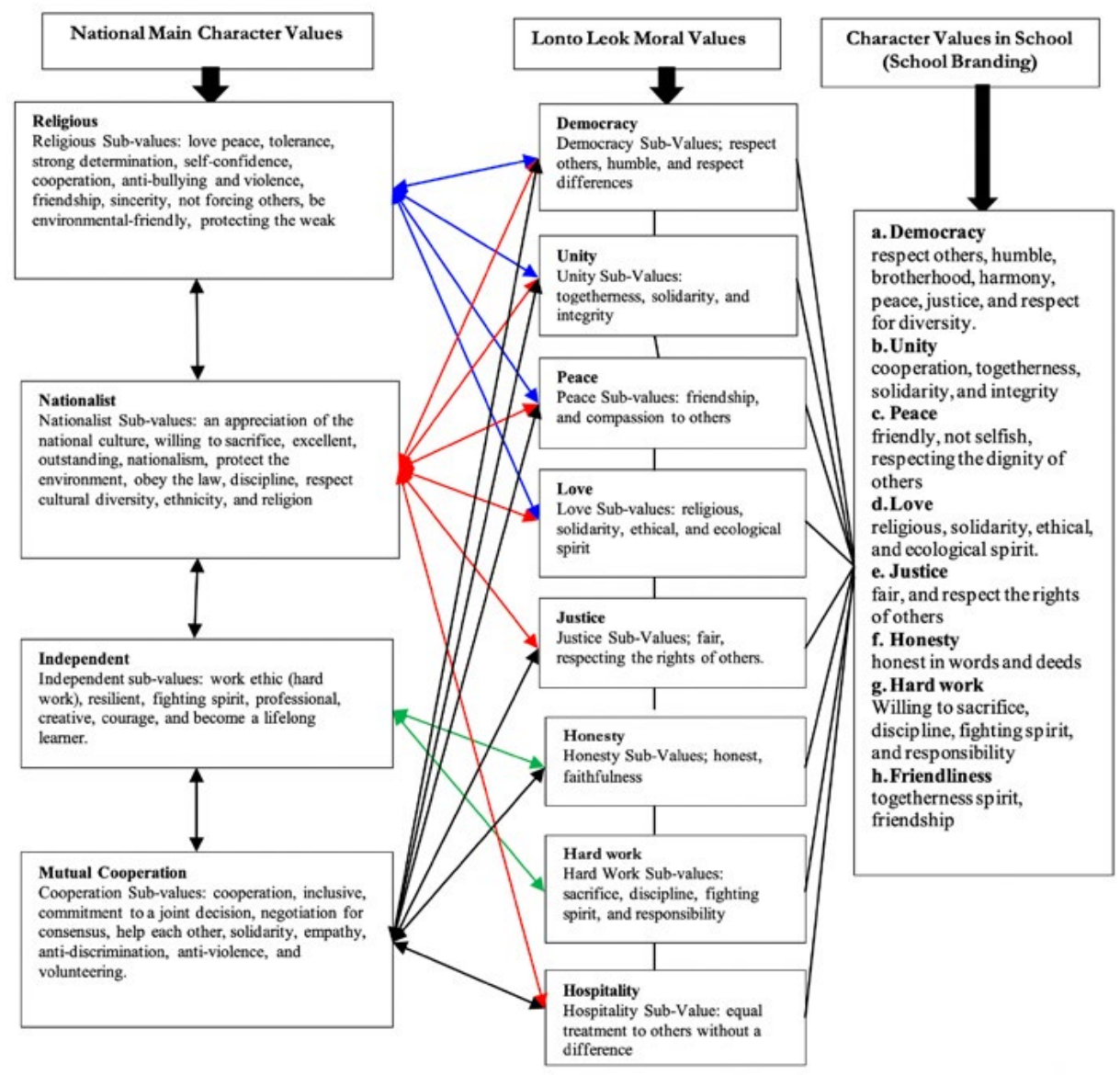

Source: Modification results, concerning: guidance from the Ministry of Education (2017); Previous researchers: Dagur (1997); Sutam (2014); Tapung et al. (2018), and the results of interviews with village elders and informants in school 
Figure 2. describes the school's character values as a result of integration. These character values are school branding and are applied through curricular and extracurricular activities. Besides, it is applied through habituation and modeling. Whereas development activities are carried out through self-development activities, class-based activities, school environment-based activities, and community-based activities.

\section{Steps of principal in implementing character education strengthening program based on lonto leok culture teaching dimension}

In implementing the character education strengthening program, the headmaster explained as follows.

For the implementation of the program, I refer to the guidelines compiled by the Indonesian Ministry of Education and Culture, which includes; personal development activities, class activities, activities in the school environment, and activities in the community environment.

Next, how the principal's role model, and how the principal uses the dimension of teaching lonto leok culture in carrying out his role, is explained in the following explanation.

First, self-development activities. The actions of the principals are: a) Encouraging all school components to work together. The Lonto Leok culture teaching dimension approach is applied in the form of "bantang cama reje leleng" (participation and cooperation), by: inviting teachers and homeroom teachers to assist students in regular school activities; controlling students in spontaneous activities. b) Encouraging and providing inspirational motivation by giving trust to teachers to find new ways of directing student behavior. The Lonto Leok teaching dimension approach is practiced in the form of "tatong" (encouraging progress and change), by: inviting the teacher to give examples of good behavior; guiding and dealing with students' problems with love and attention; inviting students to be well-behaved in the school and community environment. The intellectual stimulation from the principals is directed to empower teacher competencies, openly accept new ideas and new practices to optimize student growth and self-development.

Second, class activities. The steps of the principal's actions in-class activities are as follows. a) building a shared vision and stimulating knowledge to the teachers so that they can do more than they should. b) Providing intellectual stimulation so that teachers can design character learning (designing learning devices, models and assessment), and become competent instructors. The lonto leok teaching dimensions are given in the form of "toing" (teaching how to overcome problems), and "titong" (giving guidance to do things responsibly). Both teaching dimension are implemented by; (1) providing technical guidance to teachers, (2) providing space for freedom, fostering optimism and work creativity, (3) giving teachers freedom to describe 
the learning theories, work professionally to achieve goals, (4) encouraging teachers to assist students with love, (5) encouraging teachers to develop concrete moral behavior in schools and communities.

Third, activities in the school environment. To create a positive school culture, the principal's steps are; a) communicating character values to be shared by all school members, parents and the community, b) encouraging role-modeling and habits of teacher behavior, c) encouraging harmonious communication based on togetherness, d) school rules are flexible and not pressuring teachers and students. These steps are supported by the application of Lonto Leok teaching dimension, in the form of; "Toing" (teaching how to overcome problems), and "bantam cama reje leleng" (cooperation in teaching students). This action provides broad opportunities for teachers and students to be creative in finding new ways to create an ethical and moral school environment.

Fourth, activities in the community. The contribution of the principals in building cooperation with the community is carried out by; (1) interaction and dialogue, (2) empowering students with cultural knowledge through "lutur lewe" program (lutur: home; lewe: shared), (3) giving authority to the work team, to establish communication with tuay golo (tua: elders; golo: traditional leader) in cultural research activities, (4) discussing activities to visit traditional houses (mbaru gendang) and live with local communities. The lonto leok teaching dimension reinforces the role of the principal through "bantang cama reje leleng" (collaboration), where the community supports the character education strengthening program by providing opportunities for students to learn from the cultural environment, becoming partners in making school policies, and evaluating school programs.

In the program evaluation activities, the principal's step is offering collaborative support to develop new and more innovative ideas. Lonto leok teaching dimensions that support the role of the principal are; 'Bantam cama reje leleng' (building cooperation), developing the skills of subordinates to be responsible with their own decisions; and 'toto nai bakok' (showing support expression) by giving appreciation to the work of teachers, staff, and paying attention to the needs of teachers, staff, and students at school.

\section{Discussion}

\section{National education policy development}

The revitalization of national education policies, especially the character education strengthening program (Ministry of Education, 2017) is important and urgent to be followed up. Determining the standard of character values in schools is required. The standard of character values has been set nation- 
ally by the Ministry of Education of Indonesia. However, character values determined nationally by the Ministry of Education of Indonesia cannot be used as a standard, because they do not represent the cultural and moral values and norms of each region and tribe in Indonesia. Kleden (1987) emphasizes that Indonesia has a national culture or a culture of unity, but unity in culture it is not easy to be done since it will make confusion to what pattern it will follow. Based on national culture as a standard of the main character value, it becomes a temporary political policy, not a true and eternal pedagogical policy. Therefore, the integration of local, cultural, and moral values as one of the character value standards is highly relevant to the conditions and characteristics of the school, and these values have embedded in the life behavior of local students.

Based on this idea, the principal's policy is considered as a brave step to reinitiate a new paradigm of the direction of character education (Koesoema, 2015). By this purpose, the principal engages all school components, cultural experts, and stakeholders, to investigate, analyze, and integrate the national character values and the moral values of Lonto Leok culture, so the standard of character values used as school branding can be ensured. This combination of national characters and local, cultural, and moral values, if examined in the perspective of "Bhinneka Tunggal Ika" (meaning: Unity in Diversity), supports the five principals of Pancasila, which are described in several values. First, democracy, which positions the school environment as a place for the process of humanization (respecting the potential of students), personalization (student uniqueness), and socialization (self-actualization of students). Democracy class is used as a place for students to sharpen their mindset through discussion, research and criticize new ideas and build self-confidence (Kocoska, 2009). In discussions, the teacher's task is to provide space for freedom of speech, respect for differences of thought, provide opportunities to present material in front of the class, and class policy-making based on the results of mutual agreement. Second, unity through solid collaboration between schools, parents and the community. Intertwined with tolerant communication in the school and classroom environment. Creation of solidarity and cooperation between fellow teachers, between teachers and students, and between fellow students (Agboola \& Tsai, 2012; Koesoema, 2015). Third, peace with others, words, and actions that are polite, ethical, friendly with others. Personal who does not like a conflict with others. Teacher behavior that is patient, loving, and pleasing to students. The behavior of students who like to be friends with anyone (Wahyudin, 2018). Fourth, love is developed through three relational dimensions which include; interpersonal relations with God as homo religious (Erikson, 1958; Hegel, 1807/1979); social relations with others as homo socialae; and personal relationships with the wholeness of the universe (homo naturalae) 
(Solomon et al., 1988). It is also supported through religious studies, conditioning the school environment, habituation and exemplary of love (Lickona, 2012). Fifth, justice through habituation activities and modeling of fair actions by teachers. The same treatment of students in the school and classroom environment. There is no discrimination, objective assessment, and transparency, giving the same prizes and sanctions to all students. (Yaumi, 2014). Sixth, honesty is displayed through the right words in the school environment and in the classroom. The teacher aligns students, to be honest in working on assignments and examinations (Lickona, 1992). Seventh, hard work is described in learning behavior and the completion of independent and quality tasks (Koesoema, 2015). In the future, friendliness is presented through togetherness, friendship among teachers, teachers and students, teachers and parents and community, and between fellow students (Koesoema, 2010).

\section{Transformational leadership of principal based on lonto leok culture teaching dimension}

Overcoming the sub-optimal implementation of the character education strengthening program in Indonesia has become an important and urgent demand to improve the principal's leadership roles (Gunawan, 2014). In the context of our research, the debate over cross-cultural management is reaffirmed, relating to the specific management practices to suit the various cultural backgrounds (Schein, 1995). It is debated in terms of how well the application of management practices can be transferred across cultures (Hofstede, 1984). At this level, culture and leadership are explained in terms of two sides of the same coin (Schein, 2004). Culture and leadership cannot be understood separately: on the one hand, culture influences how the organization will interpret leadership; on the other hand, the leader's competence is the ability to get to know and work with culture. In this case, the capability to recognize the limitation of one's own culture and to describe the culture adaptively is the nature and fundamental challenge of leadership. Schein (2004) explains that a new leader replaces an existing organization if he realizes that the culture that already exists in that organization will determine and influence his leadership style. Besides, leadership in organizations is guided by pragmatic vision relating to what types of culture advancing the performance (Kotter \& Heskitt, 1993).

Therefore, leadership must be taken into account about culture (Schein, 1992; Kotter \& Heskitt, 1993; Cameron \& Quinn, 1999). Based on literary sources, it is possible to have significance between leadership and culture with measurable research design, so that the meaning of leadership and culture is found (Den Hartog, Van Muijen \& Koopman, 1996). Based on their empirical data in US and Taiwan, Spreitzer, Perttula \& Xin (2005), it is found 
that cultural values play an important role in the relationship between transformational leadership and leadership effectiveness. Bass (1997) believes that transformational leadership must work well across cultures.

As mentioned earlier, the research of Thompson, (1981) and Edwards, Edwards \& Muthaly (1995) only investigated the common experience of Australian expatriates in Thailand. This research would be different from previous research, conducted in school organizations, by: a) drawing the transformational leadership behavior in six leadership behaviors (Leithwood \& Jantzi, 1999), b) linking leadership behavior with lonto leok culture teaching dimension from Manggarai community, c) drawing the emphasis on four cultural dimensions developed by Hofstede (1984].

Besides, our research contributes to optimizing the character education strengthening in two ways. First, this research examines the impact of the distribution of principals' transformational behavior, which is supported through lonto leok culture teaching dimension approach. Previously, weaknesses in the roles of the principal were identified, so that the implementation of character education strengthening program had not been optimal. Second, it illustrates the emphasis between the lonto leok culture teaching dimension and the cultural dimension developed by Hofstede (1984).

Based on the context of our research, the character education strengthening program is implemented through self-development activities, class activities, activities in the school and community environment (Ministry of Education, 2017). Personal development activities require serious assistance from teachers and parents (Koesoema, 2010). To be effective in mentoring the teachers, the principals' transformational leadership behavior is focused on providing intellectual stimulation to teachers and parents, so that they have new initiative and innovation in assisting the students (Leithwood \& Jantzi, 1999). This principal's behavior has a positive impact because it is integrated with lonto leok culture teaching dimension approach called "tatang or titing" (empowering) teacher competence and "toing", (giving teaching/ guidance) related to student assistance, so that teachers and parents have the same concept in shaping the students' personality of (Sutam, 2014). Having the same concept means that leaders and followers have the same knowledge, mutual respect through the closeness of emotional relations and common goals (Finn, 1989). In this context, the lonto leok cultural dimension approach closing the gap of power distance between leaders and followers and building work collectivity in developing student personality (Hofstede, 1984; Tapung et al., 2018). Pillai \& Meindl (1998) found that collective-oriented-leader has a strong positive effect on group culture, personnel, and organizational performance.

Class activities require the professionalism of principal work and technical skills to design character learning models (Hudson, 2010; Leithwood 
\& Jantzi, 2006). Besides, it must show high-performance expectations, so that teachers are encouraged to work optimally in learning activities and classroom management. Teacher competencies are empowered so that they become professional learning instructors (Harvey, Royal \& Stout, 2003). To encourage professionalism in teacher work, principals use lonto leok culture teaching dimension approach in the form of "toing" (giving teaching/guidance), practical preparation of "titong" learning tools (guiding), and the steps of learning and classroom management (Lickona, 1996; Tapung et al., 2018). The principal's teaching and technical guidance to the teachers aim to avoid the uncertainty dimension to the content and learning objectives (Hofstede, 2001). The way to avoid uncertainty are; teachers must have a strong core competency and skills including critical thinking, creative, communicative and collaborative, create atmosphere that can meet the psychological needs of students, give rewards on the student learning outcomes, students are given autonomy by gaining freedom, trust, and best practices (Wibawa, 2018).

To create a positive school culture, the principal's transformational leadership behavior focuses on structure development for participation, through coordination with all internal school components, parents, and community, developing habit and role-modeling and targeting a better school vision in the future (Lickona, 1996; Leithwood \& Jantzi, 1999). The principal's leadership behavior is positive because it is combined with the lonto leok teaching dimensions in the form of; "toing" (giving teachings/guidance) in behaving, and "bantam cama reje leleng" (cooperation) which focuses on the importance of developing shared meaning and values to form a characterized school environment (Hallinger \& Heck 1998; Tapung et al., 2018) The existing cultural dimension is very effective because it emphasizes the collectivism dimension rather than individualism (Hofstede, 2001).

Community-based education is an educational model that includes the community in the education administration and management (Tilaar, 2005). The contribution of the principal's leadership in building a network of cooperation in the community is performed by; interaction and dialogue with the community and providing opportunities for teachers to develop students' knowledge so they can learn from cultural life in the community (Bass \& Steidlmeier, 1999). The lonto leok teaching dimension reinforces the leadership behavior of the principal through "bantang cama reje leleng" (collaboration). Through cooperation, the community becomes a school partner in evaluating and making school policies (Damayanti, 2017). This cultural dimension is very effective in supporting the transformational leadership behavior of principals because it closes the gap of power distance, so it will form a good relationship between leaders and subordinates as well as leaders and community (Griffith, 2004; Hofstede, 2001). 
Transformational leadership behavior of principal in evaluating character education strengthening programs leads to individual support through appreciation and meeting the needs of teachers, staff, and developing structures for participation in joint evaluation activities (Leithwood \& Jantzi, 1999). Lonto leok teaching dimension that supports the principal role in school is 'bantang cama reje leleng' (cooperation) by developing the skills of subordinates to be responsible with their own decisions, and 'toto nai bakok' (showing expression of alignments) (Sutam, 2014) through honest and sincere recognition in giving appreciation to the work of teachers, employees, appreciating contributions, fostering self-confidence, attention, trustworthiness, empathy, and paying attention to the needs of teachers, employees, and students in schools (Piccolo \& Colquitt, 2006; Moolenaar, Daly \& Sleegers, 2010) In this context, the lonto leok culture teaching dimension emphasizes gender equity and opposes individualism and domination of masculinity in traditional culture (Hofstede, 1984).

\section{Conclusion}

In recent research, the main character values in schools are determined based on the integration of national character values and the moral values of Lonto leok culture of Manggarai community. These character values become the school characteristics and have been implemented optimally in schools. These character values include; democracy, unity, peace, honesty, love, justice, hard work and friendliness. The implementation of the eight character values has an effective impact in shaping the students' character in school. The success in implementing these character values is based on the principal's transformational leadership role which is supported through lonto leok culture teaching approach in Manggarai community.

The steps of the principal's transformational leadership role in optimizing the implementation and evaluation of character education strengthening programs are; encouraging development and change through a shared vision, mission and goals; providing great opportunities to develop initiative, creativity and innovation to find new ways of solving old problems; fostering self-confidence, care, acknowledging and appreciating contributions, being trustworthy, empathetic, and meeting the needs of all school components; carrying out tasks professionally and responsibly for common good; providing inspirational motivation to do more than what subordinates should do; and encouraging cooperation (school, parents, and community). This leadership behavior is strengthened through the Lonto Leok teaching dimension approach such as; tatong (encouraging development and change), toing (teaching how to overcome problems), toto nai bakok (showing support expression), titong (giving guidance to do something responsibly), tatang or 
titing (strengthening and empowering), and bantam curing reje leleng (build cooperation between schools, parents and community).

\section{References}

Agboola, A. \& Tsai K. C. (2015). Bring Character Education Into the Classroom. European fournal Of Educational Research, 1 (2), 163-170.

Altheide, D. L., \& Johnson, J. M. (2000). Criteria for Assessing the Validity of Interpretation in Qualitative Research. In Denzin, N. K., \& Lincoln, Yv. S. (Ed.), Handbook of Qualitative Research. (2Ed.), California: Sage Publition, Inc.

Antrobus, P. (2002). Feminism as Transformational Politics: Towards possibilities for another world. Society for International Development. London \& New Delhi. Thousand Oaks CA: SAGE Publications.

Bass, B. M. (1997). Does the transactional-transformational leadership paradigm transcend organizational and national boundaries? American Psychologist, 52 (2), 130-139.

Bass, B. M., \& Steidlmeier, P. (1999). Ethics, character, and authentic transformational leadership behavior. Leadership Quarterly, 10(2), 181-218.

Batliwala, S. (2011). Feminist leadership for social transformation: Clearing the conceptual cloud. Creating Resources for Empowerment in Action (CRE) - Association for Women's Rights in Development (AWID). Retrieved November 23, 2019, from http://web.creaworld. org/files/f1.pdf.

Bond, T. (2004). An introduction to the ethical guidelines for counselling and psychotherapy. Counselling and Psychotherapy Research, 4(2), 4-9. doi:10.1080/14733140412331383883

Cameron, K. S., \& Quinn, R. E. (1999). Diagnosing and changing organizational culture. Reading: Addison-Wesley.

Cook, L. A., Smith, W. S., Lan, W. Y., \& Carpenter, D. (2016). The development of global competencies and global mindedness through global education experiences. International fournal of Global Education, 5 (2), 1-15

Colbert, B. A., Nicholson, J., \& Kurucz, E. C. (2018). Humanistic leadership for sustainable transformation. Evolving Leadership for Collective Wellbeing, 33-47. doi:10.1108/s205888012018000000700

Character Education Partnership. (2002). Eleven principles of effective character education. Retrieved July 28, 2002, from http://www.character.org/principles/

Creswell, J. W. (2009). Research design. qualitative, quantitative, and mixed method approaches. Los Angeles: SAGE Publications, Inc.

Dagur, B. A. (1997). Manggarai culture as one of the treasures of national culture. Jakarta: Ubhara Press.

Damayanti, D. (2017). Principal's Managerial Ability, School Climate, and Primary School Quality. Education Administration, vol 24(1), 154-162.

DeCavalho, R. J. (1991). The humanistic Paradigm in Education. The Humanistic Psychologist, $19(1), 88-104$.

Den Hartog, D. N., Van Muijen, J. J., \& Koopman, P. L. (1996). Linking transformational leadership and organizational culture. Journal of Leadership Studies, 3 (4), 68-83.

Den Hartog, D. N., House, R. J., Hanges, P. J., Ruiz-Quintanilla, S. A., Dorfman, P. W., Abdalla, I. A., Akande, A. (1999). Culture-specific and cross-culturally generalizable implicit leadership theories. The Leadership Quarterly, 10 (2), 219-256. 
Denzin, N. K., Lincoln \& Lincoln, Yv. S. (2000). Handbook of Qualitative Research (Eds.). California: Sage Publication, Inc.

Dister, N. S. (1998). Filsafat Kebebasan. Yogyakarta: Kanisius.

Edwards, R., Edwards, J., \& Muthaly, S. (1995). Doing business in thailand: Essential background knowledge and first hand advice, Melbourne: Asian Business Research Unit, Monash University.

Endah, S. (2012). Implementation of the character education curriculum. Yogyakarta: Citra Aji Parama.

Erikson, E. (1958). Young Man Luther: A study in psychoanalysis and history. New York: W. W. Norton.

Erickson, F. (1997). Culture in Society and in Educational Practices. Multicultural Education: Issues and Perspectives, 3rd ed., ed. J. A. Banks and C. A. M. Banks Boston: Allyn \& Bacon.

Ferraro, G. P. (1998). The Cultural dimensions of international business. Prentice-Hall: Englewood Clifffs.

Finn, J. D. (1989). Withdrawing from school. Review of Educational Research, 59(2), 117-143.

Freire, P. (1978). A Pedagogy for liberation: Dialogues on transforming education. The United State America: Bergins \& Garvey Publishers, Inc.

Gerstner, C. R., \& Day, D. V. (1994). A Cross-cultural comparison of leadership prototypes. Leadership Quarterly, 5 (2), 121-134.

Giddens A. (2003). Runaway world: How globalization is reshaping our lives. Washington DC: Taylor \& Francis.

Government Regulation (GR) No. 87 of 2017 concerning strengthening character education. Jakarta: Sekretariat Pusat.

Gunawan, H. (2014). Character education: Concepts and implementation. Bandung: Alfabeta.

Griffith, J. (2004). Relation of principal transformational leadership to school staff job satisfaction, staff turnover, and school performance. Fournal of Educational Administration, 42(3), 333-356.

Groome, T. (1991) Sharing faith: A Comprehensive approach to religious education and pastoral ministry. San Francisco: Harper \& Collins.

Hallinger, P., \& Heck, R. H. (1998). Exploring the principal's contribution to school effectiveness: 1980-1995. school effectiveness and school improvement, An International Journal of Research, Policy and Practice, 9, 157-191. doi.org/10.1080/0924345980090203

Harvey, S., Royal, M., \& Stout, D. (2003). Instructor's Transformational Leadership: University Student Attitude and Ratings. Psychological Reports, 92, 395-402.

Hegel, G. (1807/1979). Phenomenology of Spirit. Oxford: Oxford University Press.

Hintze, Denna,. Knut Are Romann-Aas,. Hanne Kristin Aas (2015). Between You and Me: A Comparison of Proximity Ethics and Process Education. International Journal of Process Education 7 (1), 3-20.

Hofstede, G. (1984). Cultures consequences: International differences in work-related values, abridged (ed.), Beverly Hills: Sage Publications.

Hofstede, G. (1993). Cultural constraints in management theories. Academy of Management Executive 7, 81-94. doi.org/10.5465/ame.1993.9409142061

Hofstede, G. (2001). Culture's consequences: Comparing values, behaviors, institutions, and organizations across nations. Thousand Oaks, CA: Sage. 
House, R. J., Hanges, P. J., Javidan, M., Dorfman, P. W., Gupta, V. (2004). Culture, leadership and organizations: the globe study of 62 societies. Thousand Oaks, CA: Sage.

Hudson, P. (2010). Mentors report on their own mentoring practices. Australian fournal of Teacher Education, 35(7), 30-42.

Kasali, R. (2017). Disruption: Nothing can be changed before it is faced, motivation is not enough. Jakarta: Gramedia Pustaka Utama

Kleden, I. (1987). Scientific attitudes and cultural criticism. Jakarta : LP3ES.

Kocoska, J. (2009). The student's position in the democratic classroom, in the world conference on educational sciences. Procedia Social and Behavioral Sciences, 1, 2429-2431.

Koentjaraningrat. (1998). Manusia dan kebudayaan di Indonesia. Jakarta: Djambatan.

Koesoema, D. A. (2010). Character education: Strategies to educate children in the global age. Jakarta: Grasindo.

Koesoema, D. A. (2015). Character education strategy, mental revolution in educational institutions. Yogyakarta: Kanisius.

Kotter, J. P., \& Heskett, J. L. (1993). Culture et performances: le second souffle de l'entreprise. Editions d'Organisation.

Ladson-Billings, G. (1992c). Reading between the lines and beyond the pages: A culturally relevant approach to literacy teaching. Theory Into Practice, 31, 312-320.

Leithwood, K., \& Jantzi, D. (1999). Transformational school leadership effects: A Replication. School Effectiveness and School Improvement, 10 (4), 451-479.

Leithwood, K., Jantzi, D. (2006). Transformational school leadership for large-scale reform: Effects on students, teachers, and their classroom practices. School Effectiveness and School Improvement. 17, 201-227.

Li, Y. (2013). Cultivating student global competence: A Pilot experimental study. Decision Sciences fournal of Innovative Education, 11(1), 125-143.

Lickona, T. (1996). Raising good children: From birth through the teenage years. New York: Bantam Books.

Lickona, T. (2004) Character matter: How to help our children develop good judgment, integrity, and other essential virtues. New York: Touchstone.

Lickona, T. (2012). Education for character: Educate to shape character. Jakarta: PT Bumi Aksara.

Lovvorn, A. S., \& Chen, J. S. (2011). Developing a global mindset: The relationship between and international assignment and cultural intelligence. International fournal of Business and Social Science, 2(9), 275-283.

Mason, M. (2013). Educational inequality and educational quality. International fournal of Educational Development. (34) 1-2.

Miles, M., B., Huberman, A., M., \& Saldaña, J. (2014). Qualitative data analysis: a methods sourcebook, (Third edition). Arizona State University: SAGE Publications, Inc.

Moolenaar, N. M., Daly, A. J. \& Sleegers, P. J. C. (2010). Occupying the principal position: examining relationships between transformational leadership, social network position, and schools' innovative climate. Educational Administration Quarterly. 46(5), 623- 670.

Musana, A. (2011). Rationality and actuality of local wisdom as a base for character education. Fournal of Education and Culture, 17 (6), 588-598.

Nieto, S. (2008). Chapter 9: Culture and education1. Yearbook of the National Society for the Study of Education, 107(1), 127-142. 
Vassell, L. (2004). Feminisms, gender studies, activism: The Elusive triad. In b. Bailey \& E. Leorhyni (Eds.). Gendern the 21st century: caribbean perspectives, visions and possibilities. Kingston: Ian Randle Publishers.

Piccolo, R. F., \& Colquitt, J. A. (2006). Transformational leadership and job behaviors: the mediating role of core job characteristics. Academy of Management fournal. 49, 327-340. doi.org/10.5465/AMJ.2006.20786079

Pillai, R., \& Meindl, J. R. (1998). Context and charisma: A "Meso" level examination of the relationship of organic structure, collectivism, and crisis to charismatic leadership. Journal of Management, 24, 643-671.

Podsakoff, P. M., MacKenzie, S. B., Moorman, R. H. \& Fetter, R. (1990). Transformational leader behaviors and their effects on followers' trust in leader, satisfaction, and organizational citizenship behaviors. The Leadership Quarterly, 1(2), 107-142.

Rahardjo, D. (1998). Korupsi, kolusi dan nepotisme kajian konseptual dan sosiokultural, dalam menyingkap korupsi, kolusi dan nepotisme di indonesia. Yogyakarta: Aditya Media.

Ryan, K., \& Bohlin, K. E. (1999). Building Character in Schools: Practical Ways to Bring Moral Instruction to Life. San Francisco: Jossey -Bass.

Schein, H. E. (1995). Organizational and Managerial Culture as a Facilitator or Inhibitor of Organizational Transformation. Singapore: Paper presented to the Inaugural Assembly of Chief Executive and Employers.

Schein, E. H. (2004). Organizational culture and leadership (3rd ed.). San Francisco, CA: Jossey-Bass.

Soekmono. (1973). Pengantar Sejarah Kebudayaan Indonesia. Yogyakarta: Kanisius.

Solomon, D., Watson, M., Delucchi, K., Schaps, E., \& Battistich, V. (1988). Enhancing children's prosocial behavior in the classroom. American Educational Research fournal, 25, 527-554.

Spreitzer, G. M., Perttula, K. H., \& Xin, K. (2005). Traditionality matters: an examination of the effectiveness of transformational leadership in the United States and Taiwan. fournal of Organizational Behavior, 26(3), 205-227.

Sutam, I. (2014). Education in the Manggarai cultural perspective. Ruteng: STKIP St. Paulus.

Tapung, M., Maryani, E., Lon, Y., Payong, M. \& Supriatna, N. (2018). Developing the Value of "Lonto Leok" in Manggarai Culture to Empower the Skills of Social Problem-Solving in Social-Sciences Learning of Junior-High School. In Proceedings of the Annual Conference on Social Sciences and Humanities (ANCOSH 2018).

The Ministry of Education and Culture Republic of Indonesia. (2016). Strengthening character education. Jakarta: Secretariat Team for Strengthening Character Education.

The Ministry of Education and Culture Republic of Indonesia. (2017). Strengthening character education training modules for school principals. Jakarta: Secretariat Team for Strengthening Character Education.

Thompson, A. (1981). The Establishment and operating experiences of australian companies in thailand, Melbourne: Melbourne University.

Tilaar, H. A. R. (2005). National education manifesto review of postmodernism and cultural studies. Jakarta: Kompas.

Todd, S. (2001). Guilt, suffering and responsibility. Journal of Philosophy of Education, 35 (4), 598-614.

Triandis, H.C. (1994). Culture and social behaviour. U.S: McGraw-Hill. 
UNESCO. (2012). Education Sustainable Development. Sourcebook. Paris France: the United Nations Educational, Scientific and Cultural Organization Publication.

United Nations (2016). Global sustainable development report 2016. New York. Department of Economic and Social Affairs.

Veugelers, W. (Eds.). (2008). Getting involved. Global citizenship development and sources of moral values. In education and humanism; Linking autonomy and humanity, AW Rotterdam,The Netherlands, Retrieved from: www.sensepublishers.com.peter.deliefde@ sensepublishersc.om

Verhejen. (1970). Manggarai II dictionary: Indonesian-Manggarai. Ende: Percetakan Arnoldus.

Waddock, S. (2016). Developing humanistic leadership education. Humanist Management fournal, 1, 57-73.

Wahyudin, D. (2018). Peace Education Curriculum In The Context Of Education Sustainable Development (ESD). Journal of Sustainable Development Education and Research. 2 (1), 21-32.

Werhane, P. H. (2008). Mental models, mental models, moral imagination and system thinking in the age of globalization. Fournal of Business Ethics, 78, 463-474.

Wibawa, S. (2018). Education in the era of the industrial revolution 4.0. Indonesia, Jakarta: Pustaka pelajar.

Wibowo, A. (2015). Management of character education in schools.Yogyakarta: Pustaka Pelajar.

Yaumi, M. (2014). Character education: Platform, supporting poles \& implementation. Jakarta: Predanamedia Group.

Yin, R. K. (2017). Case study research and applications: Design and methods. London: Sage publications. 